\title{
O USO DO CIM (CITY INFORMATION MODELING) PARA GERAÇÃO DE IMPLANTAÇÃO EM CONJUNTOS DE HABITAÇÃO DE INTERESSE SOCIAL: UMA EXPERIÊNCIA DE ENSINO'1
}

\author{
CIM (CITY INFORMATION MODELING) FOR THE GENERATION OF SITE \\ LAYOUTS FOR SOCIAL HOUSING COMPLEXES: A TEACHING EXPERIENCE
}

\author{
José Nuno Beirão \\ Universidade de Lisboa (UL) \\ inb@fa.ulisboa.pt \\ Leticia Teixeira Mendes \\ Universidade Federal de Pernambuco (UFPE) \\ leticia.mendes@ufpe.br \\ Gabriela Celani \\ Universidade Estadual de Campinas (UNICAMP) \\ celani@fec.unicamp.br
}

\begin{abstract}
Resumo
A questão da habitação e os paradigmas que envolvem o habitar humano na contemporaneidade têm sido uma temática recorrente no panorama arquitetônico do século XXI; assim, torna-se necessário entendê-los como elementos fundamentais na estruturação das cidades. Essa problemática se intensifica ao analisarmos o tema da habitação de interesse social (HIS) e seu impacto na qualidade de vida dos habitantes, e como consequência, das cidades brasileiras. O presente trabalho é parte dos resultados de uma pesquisa de doutorado que utilizou o formalismo da gramática da forma e a abordagem da modelagem paramétrica como métodos para a geração de espaços públicos em conjuntos de HIS no Brasil, assumindo que essa metodologia pode contribuir para uma exploração mais ampla e aprofundada de diferentes soluções projetuais. A fim de testar o método proposto foram organizados três workshops com alunos do curso de Arquitetura e Urbanismo da Faculdade de Engenharia Civil, Arquitetura e Urbanismo, da Universidade Estadual de Campinas. Cada workshop foi direcionado para diferentes escalas do projeto de um conjunto habitacional: (1) desenho urbano, (2) implantação urbana do conjunto habitacional e (3) relação entre os edifícios e os espaços externos. Este artigo apresentará os resultados obtidos no workshop (1), denominado Parametric Urban Design.
\end{abstract}

Palavras-chave: Modelagem paramétrica. City Information Modeling. Habitação de Interesse Social.

\begin{abstract}
The issue of housing and the paradigms related to human dwelling in the contemporary world have been a recurrent topic in the 21st architectural scenario; therefore, it is necessary to understand them as fundamental elements in the structuring of cities. This issue is even more relevant when we consider low-income housing and its impact on the life quality of people, and therefore of Brazilian cities. This paper presents part of the results of a $\mathrm{PhD}$ research that used the Shape Grammar formalism and the parametric modeling approach as methods for the generation of public spaces in low-income housing developments in Brazil. The research assumed that these
\end{abstract}

1 BEIRÃO, J. N.; MENDES, L. T.; CELANI, G. O uso do CIM (City Information Modeling) para geração de implantação em conjuntos de habitação de interesse social: uma experiência de ensino. In: ENCONTRO BRASILEIRO DE TECNOLOGIA DE INFORMAÇÃO E COMUNICAÇÃO NA CONSTRUÇÃO, 7, 2015 , Recife. Anais... Porto Alegre: ANTAC, 2015. 
methods could contribute to the generation of a broader number of design alternative solutions. Aiming to test the proposed method, three workshops were offered to the University of Campinas' Architecture and Urban Design students. Each workshop focused on a different design scale: (1) urban design, (2) site planning of the complex and (3) spatial relations between buildings and open spaces. In this paper the results of the first workshop, titled Parametric Urban Design, are described.

Keywords: Parametric design. City Information Modeling. Low-income housing.

DOI: http://dx.doi.org/10.11606/gtp.v10i2.102564 